\title{
Rapid Assessment of the Sex Ratio of the Fiddler Crab, Uca tangeri, in Two Mangrove Habitats on the Bonny River
}

\author{
M. Torle ${ }^{1}$, M. Miebaka ${ }^{1}$ and J. Onwuteaka ${ }^{1^{*}}$ \\ ${ }^{1}$ Rivers State University, Port Harcourt, Nigeria.
}

Authors' contributions

This work was carried out in collaboration among all authors. Authors MT and JO designed the study, performed the statistical analysis, wrote the protocol and wrote the first draft of the manuscript. Authors MM and JO managed the analyses of the study. Author JO managed the literature searches.

All authors read and approved the final manuscript.

Article Information

DOI: $10.9734 / A R R B / 2019 / v 31$ i430058

Editor(s):

(1) Dr. Tunira Bhadauria, Professor, Department of Zoology, Feroze Gandhi Post Graduate College, Kanpur University, U .P,

(2) Dr. George Perry, Dean and Professor of Biology, University of Texas at San Antonio, USA.

Reviewers:

(1) Ndueso U. Ikot, University of Calabar, Nigeria.

(2) Dr. Grishma Tewari, Guru Angad Dev Veterinary and Animal Sciences University, India

(3) Dr. Mahmoud Abdelhamid Dawood, Kafrelsheikh University, Egypt. Complete Peer review History: http://www.sdiarticle3.com/review-history/47957

Original Research Article

Received 13 January 2019

Accepted 02 April 2019

Published 16 April 2019

\section{ABSTRACT}

A rapid assessment of the sex ratio of the fiddler crab, Uca tangeri, was undertaken in two mangrove habitats on the Bonny River which were undergoing intense human impact as a result of dredging and urbanization activities. The contrasting adult sex ratios of $4: 1$ of male to female at Eagle Island and 1:2.6 at Rumuolumini and or juveniles showing 2.4:1 (Eagle Island) and 1:1.8 (Rumuolumini) were highly significant ( $\mathrm{X} 2$ test, $\mathrm{P}<0.05)$. This shows evidence of studies supporting deviation in Uca spp from the 1:1 proportion. Evidence of anthropogenic activity and intensive socioeconomic exploitation provided no explanation for the contrasting high deviation in ratio of males to females between Eagle Island and Rumuolumeni habitats. Megalopae settlement is evident but the physical, chemical and interspecific cues that determine gender balance are necessary for any intended future conservation planning. 
Keywords: Sex ratio; Uca tangeri; Bonny River; mangrove; Eagle Island and Rumuolumeni.

\section{INTRODUCTION}

Fiddler crabs, as important members of the intertidal mangrove forests mudflat, play an important role in structural and functional estuarine and marine ecosystems. Their tolerance of salinity fluctuation, high temperature and low oxygen levels in the estuarine environment may be one of the factors responsible for their survivability [1]. Fiddler crabs breathe with their gills under their carapace while in water and trap oxygen with moist dendritic gills when on land [2]. They serve as links at the mangrove trophic level. Such links include serving as bait in fisheries and as protein security when used by the local communities for food. This makes them important in the provision of ecosystem services. They also form the bulk component of the food web for young crocodiles, otters, civets, and birds. Uca tangeri are also important in traditional and pharmaceutical applications as they are excellent sources of chitosan and chitin and are delicacies in rural communities. They constitute one of the major parts of the zooplankton community linking the food web of the mangrove, serving as prey to amphibians, crustaceans, fishes, birds, jelly fish, small mammals and reptiles [3] and also as important regulators of cord grass [4].

In mangrove ecosystems, one of the determinants of population structure is sex ratio which helps in showing the reproductive effort. Sex ratio which is the ratio of males to females in a given population provides a basis for further assessment of the influence of biotic and abiotic conditions on a crab population. The sex ratio of the fiddler crab population has been a topic of high debate for many years. In an unaltered population, the proportion of males and females at birth has been seen to tend towards 1:1 [5]. However, Gregatti and Negrerio-Fransozo [6] suggest that, after birth, several ecological factors such as mortality rate, migration rate, longevity, growth, predation, habitat speciation by the two sexes and processes of reproduction tend to tilt the population towards male domination. Also, overfishing has been shown to deviate this trend towards female [7] domination. In the Niger Delta, which contains the third largest mangrove, in the world, the unplanned destruction of the habitats of Uca tangeri is of great concern to conservation scientists. Both the mangrove and Uca tangeri depend on each other ecologically. Uca currently provides many ecosystem services to communities living in the mangroves. In the face of the rapid destruction of the mangrove, this study conducted a rapid assessment of sex ratio in two mangrove habitats. The objective was to know if the population structure is similar in order to provide conservation biologists a basis for intervention.

\section{MATERIALS AND METHODS}

Uca tangeri samples were collected from the coordinates $04048133.711 \quad \mathrm{~N}$ and $06055143.211 \mathrm{E}$, located at Rumuolumeni and $04046151.511 \mathrm{~N}$ and $006058141.111 \mathrm{E}$ at Eagle Island (Fig. 1). Both sites are on the tributaries of Bonny River in Nigeria. Both sites experience diurnal tidal cycles and have mangrove vegetation such as Rhozophora mangle and Avicennia africana. Samples were collected weekly from both sites for three months, between September and November 2017. September represents the peak of the raining season while November represents the early beginning of the dry season.

Three hundred and sixty (360) fiddler crab samples were collected per study station. In the laboratory, samples were preserved in 10\% formalin. Samples were sexed as male, female and aged (adult and juvenile) by morphological observation of claw size, abdominal and carapace regions. Sex ratio was determined from the number of specimens of each sex sampled every month in every size group. In order to determine the distribution of males and females, the sex ratio values obtained were subjected to chi-square test [8] by employing the formula $\mathrm{X} 2=$ $\Sigma[(0-e) 2 / e]$, where $0=$ observed number and $\mathrm{e}=$ expected number.

Sex ratio $=$ No. of female crabs $/$ No. of male crab

A questionnaire was administered to the communities living close to the habitats in order to measure the impact of human exploitation on the crab community as they are used for food, commerce, traditional medicine, religious purposes and trap material in artisanal fisheries. 


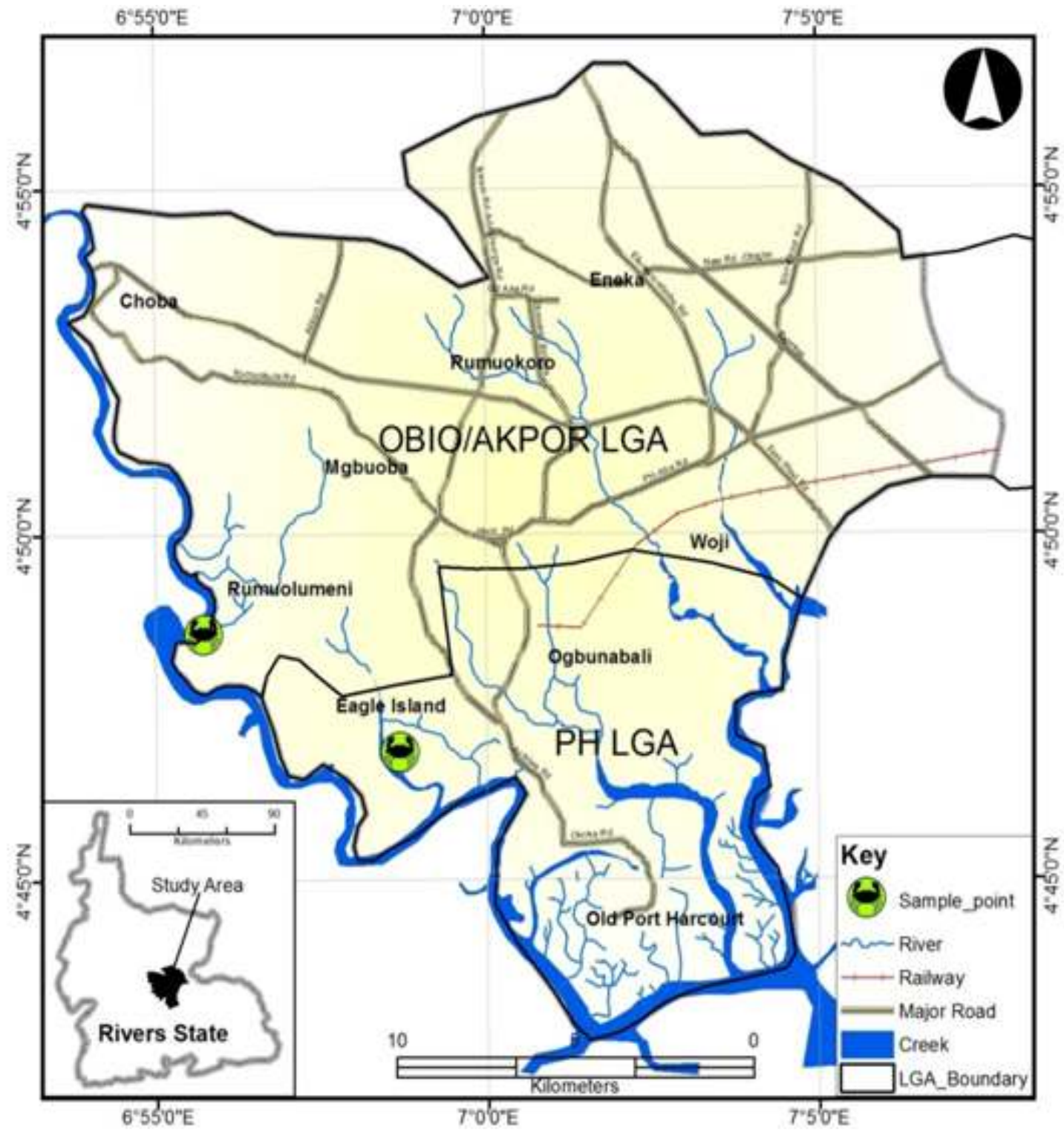

Fig. 1. Map of the study area

\section{RESULTS}

Figs. 2 and 3 present the weekly mean percentage sex ratio of adults and juveniles from Eagle Island and Rumuolumeni stations. At the Eagle Island station, adult male crabs contributed $>60 \%$ to the sampled population throughout the weeks of sampling. There was evidence of an outlier data in week 1 where the male crabs were hundred percent $(100 \%)$. In the same period, the contribution of male juvenile crabs varied from $30 \%$ to $90 \%$ being lowest in week two and highest at week eight. There is evidence of the absence of juveniles in week one.

At Rumuolumeni station (Fig. 4), adult male crabs contributed $<10 \%$ to a maximum of $40 \%$ to the sampled population throughout the weeks of sampling. In the same period, the contribution of male juvenile crabs to the sampled population varied from the highest value of $75 \%$ in week five to the lowest value of $15 \%$ in week eleven (Fig. 5). At Rumuolumeni, juveniles were present unlike at Eagle Island. 


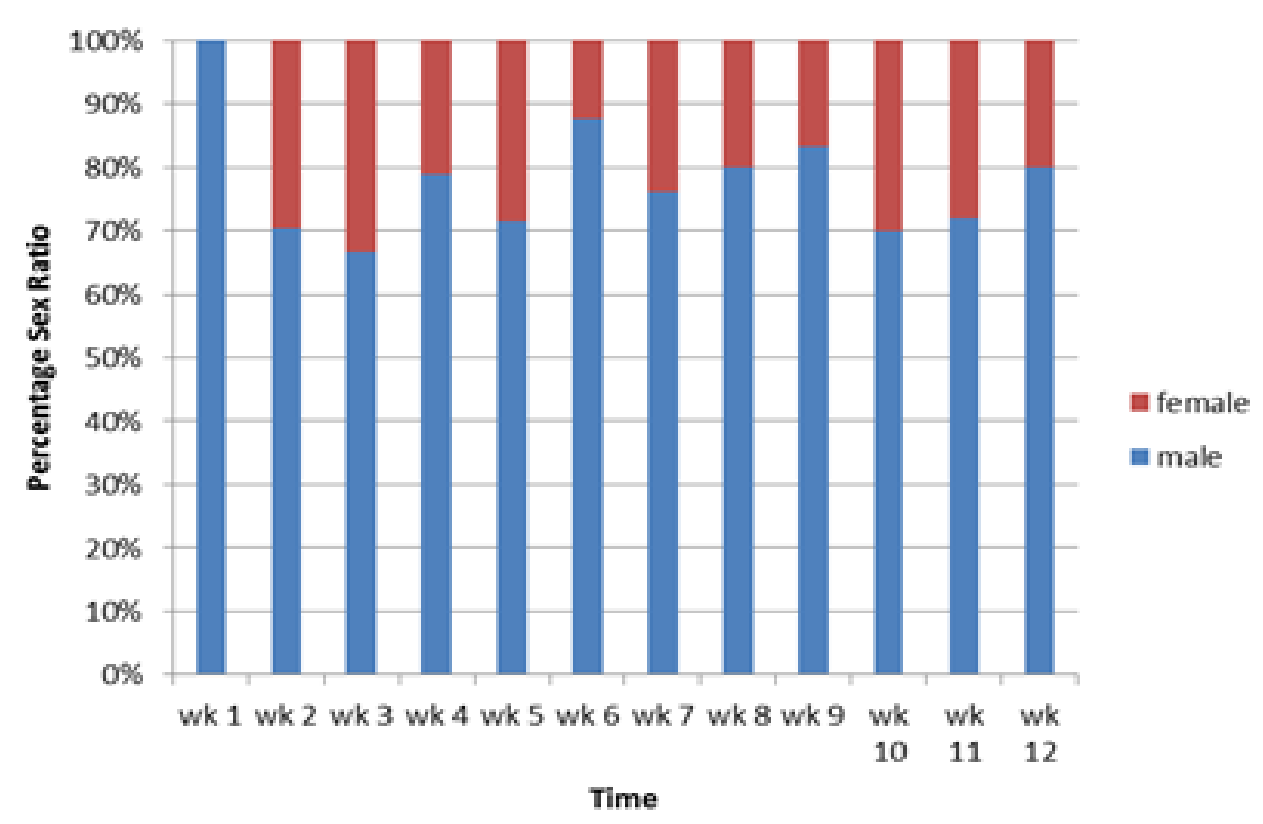

Fig. 2. Percentage weekly sex ratio of adult males and females at Eagle Island

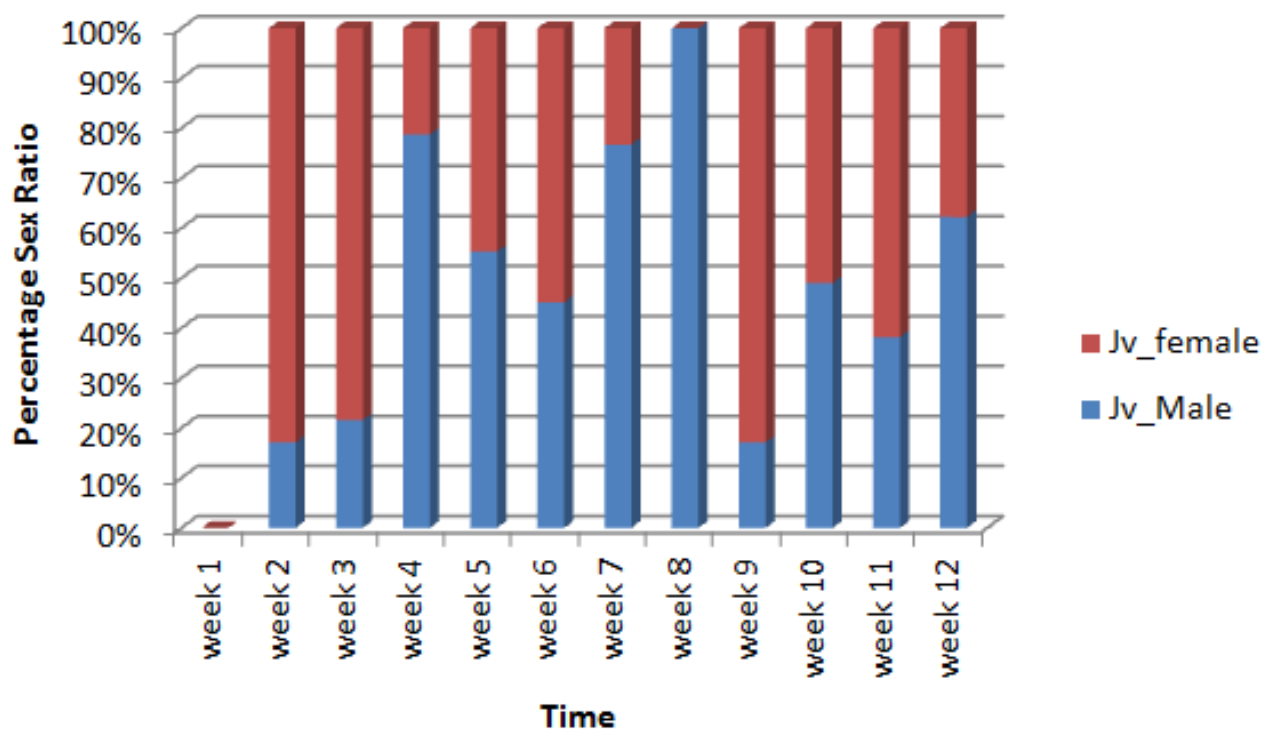

Fig. 3. Percentage weekly sex ratio of juvenile male and female at Eagle Island

Figs. 6 and 7 show the size classes of adult male crabs at Rumuolumeni and Eagle Island respectively. Nine size classes were observed at Rumuolumeni (Fig. 6), having a minimum class of 2.7 to $2.9 \mathrm{~cm}$, a maximum class of 4.5 to 4.7 $\mathrm{cm}$, from a class interval of $0.2 \mathrm{~cm}$. Size class 3.9 to $4.1 \mathrm{~cm}$ had the highest percentage of adult male crabs $(36 \%)$, followed in decreasing order by class 3.5 to $3.7 \mathrm{~cm}(18 \%)$, class 3.1 to $3.3 \mathrm{~cm}$ $(16 \%)$, while class 2.7 to $2.9 \mathrm{~cm}$ had the least percentage of crabs (2\%). Similarly, nine size classes were observed at Eagle Island (Fig. 7), having a minimum class of 2.5 to $2.7 \mathrm{~cm}$, a maximum class 4.1 to $4.3 \mathrm{~cm}$, and a class interval of $0.2 \mathrm{~cm}$. In decreasing order, size class 3.9 to $4.1 \mathrm{~cm}$ had the highest percentage of adult crabs $(30 \%)$, followed closely by size class 3.5 to $3.7 \mathrm{~cm}$ (23\%), class 3.7 to $3.9 \mathrm{~cm}(17 \%)$, and least class of 2.5 to $2.7 \mathrm{~cm}$ $(0.4 \%)$. 


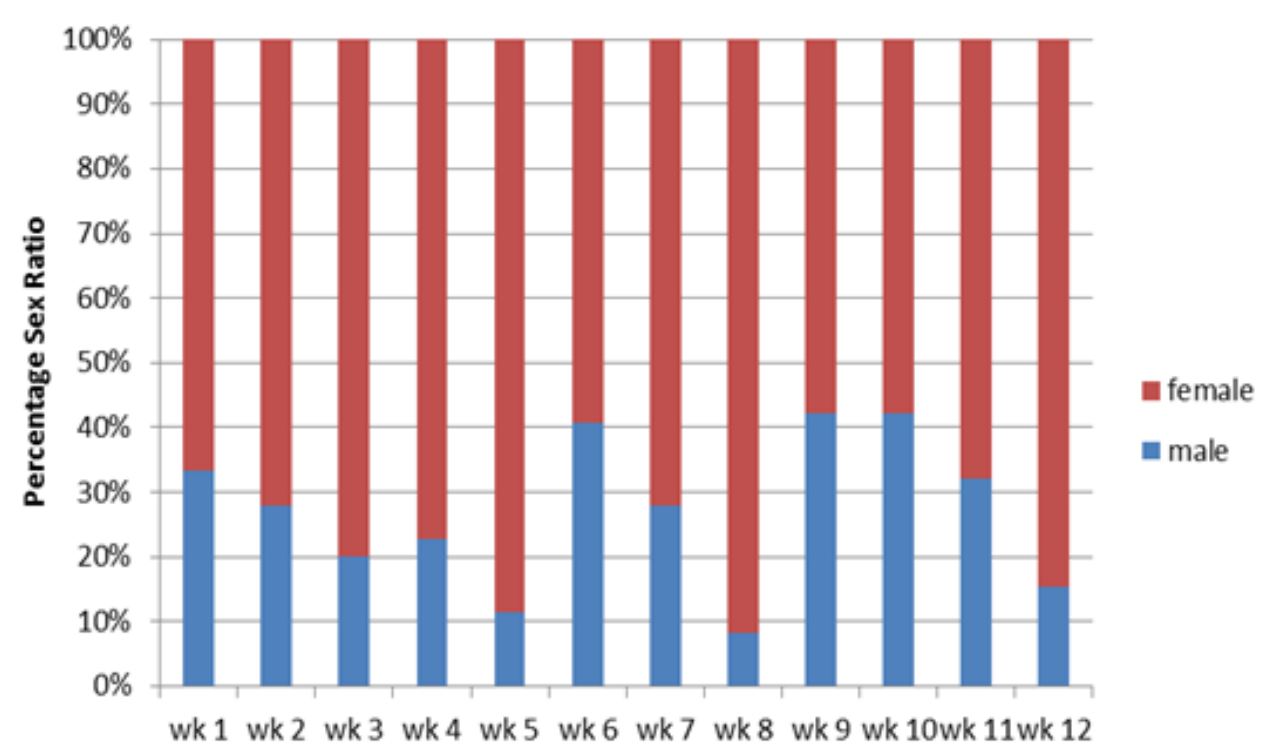

Time

Fig. 4. Percentage weekly sex ratio of adult males and females at Rumuolumeni

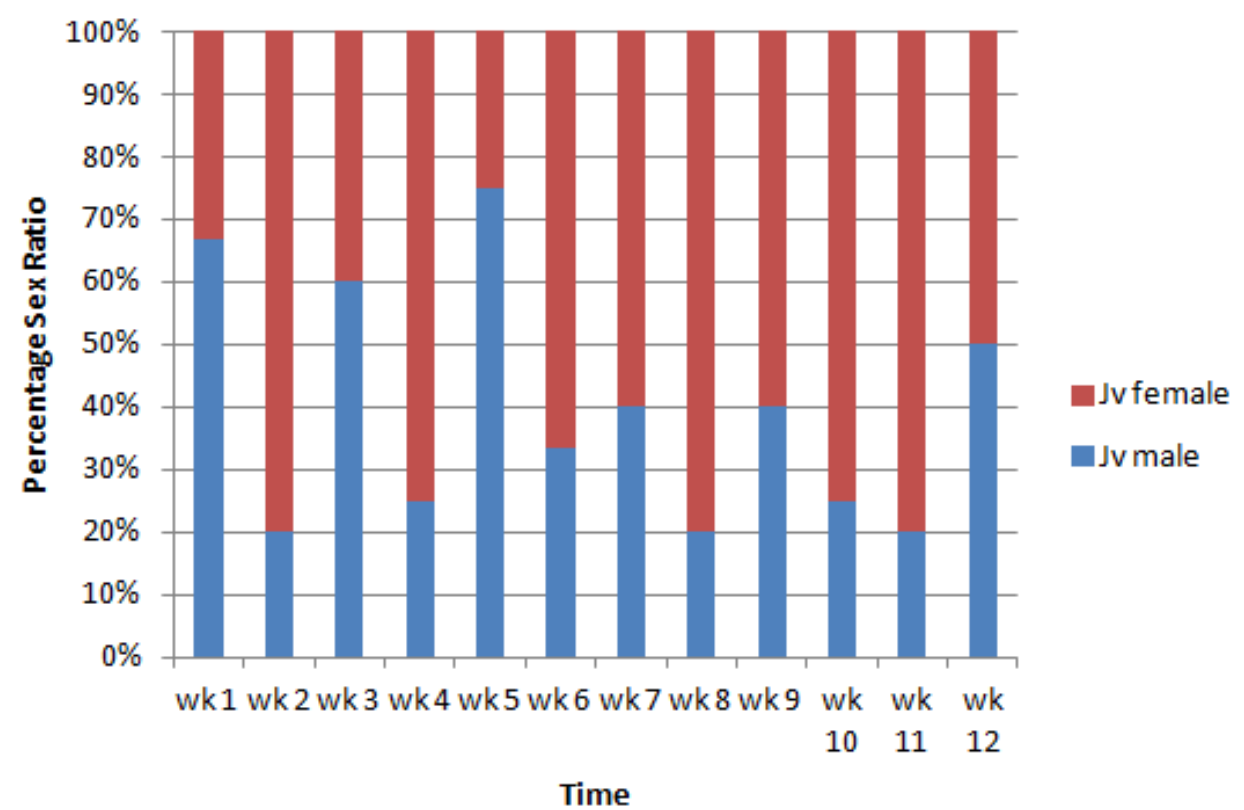

Fig. 5. Percentage weekly sex ratio of juvenile male and female at Rumuolumeni

Figs. 8 and 9 show the size classes of juvenile male crabs at Rumuolumeni and Eagle Island respectively. Six size classes were observed at Rumuolumeni (Fig. 8), having a minimum class of 2.2 to $2.3 \mathrm{~cm}$, a maximum class of 2.8 to $2.9 \mathrm{~cm}$, in a class interval of $0.1 \mathrm{~cm}$. Size class 2.2 to $2.3 \mathrm{~cm}$ had the highest percentage of juvenile male crabs (45\%), followed in decreasing order by class 2.4 to 2.5 and 2.5 to $2.6 \mathrm{~cm}$ (15\% each), while class 2.8 to $2.9 \mathrm{~cm}$ had the least percentage of crabs $(5 \%)$. Meanwhile, nine size classes were observed at Eagle Island (Fig. 9), having a minimum class of 0.6 to $0.7 \mathrm{~cm}$ occurring at $4 \%$ and the highest percentage of $25 \%$ occurrence in size class 2.4 $2.5 \mathrm{~cm}$. 


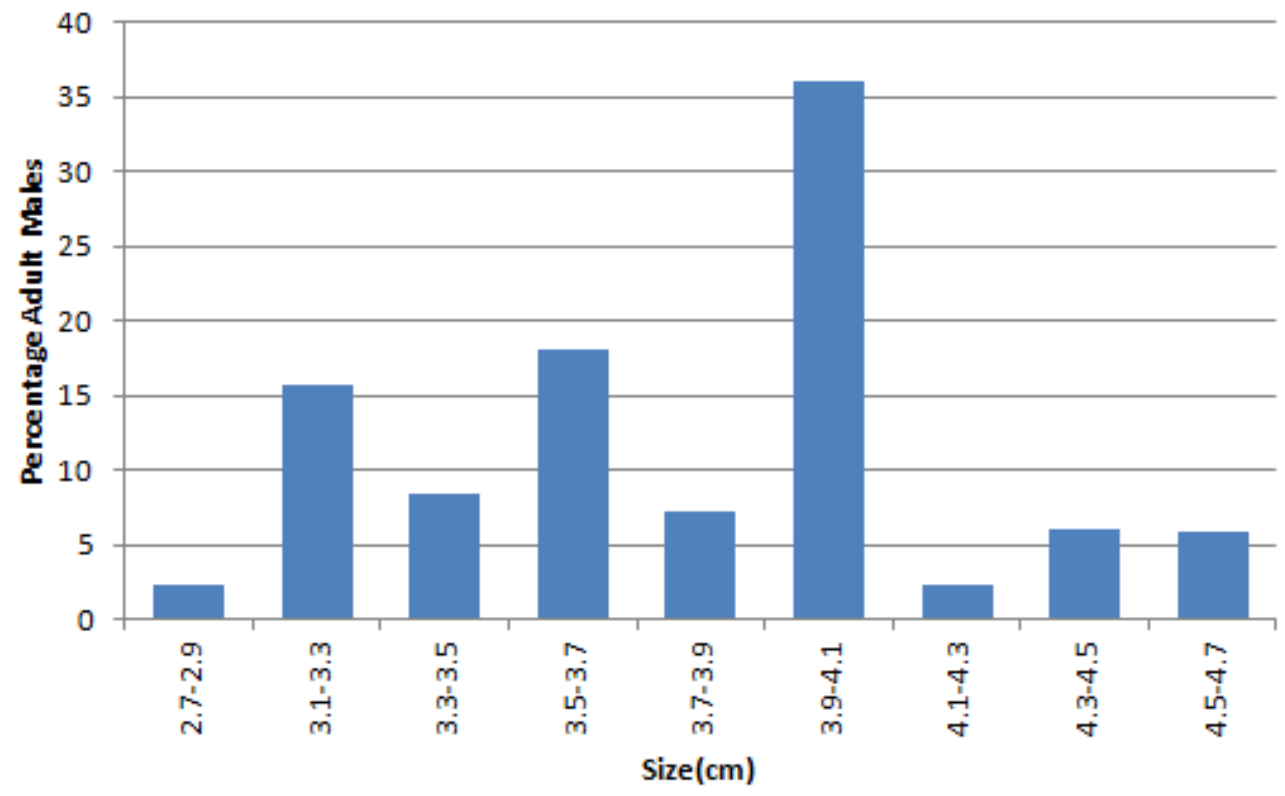

Fig. 6. Size classes of adult male crabs at Rumuolumeni

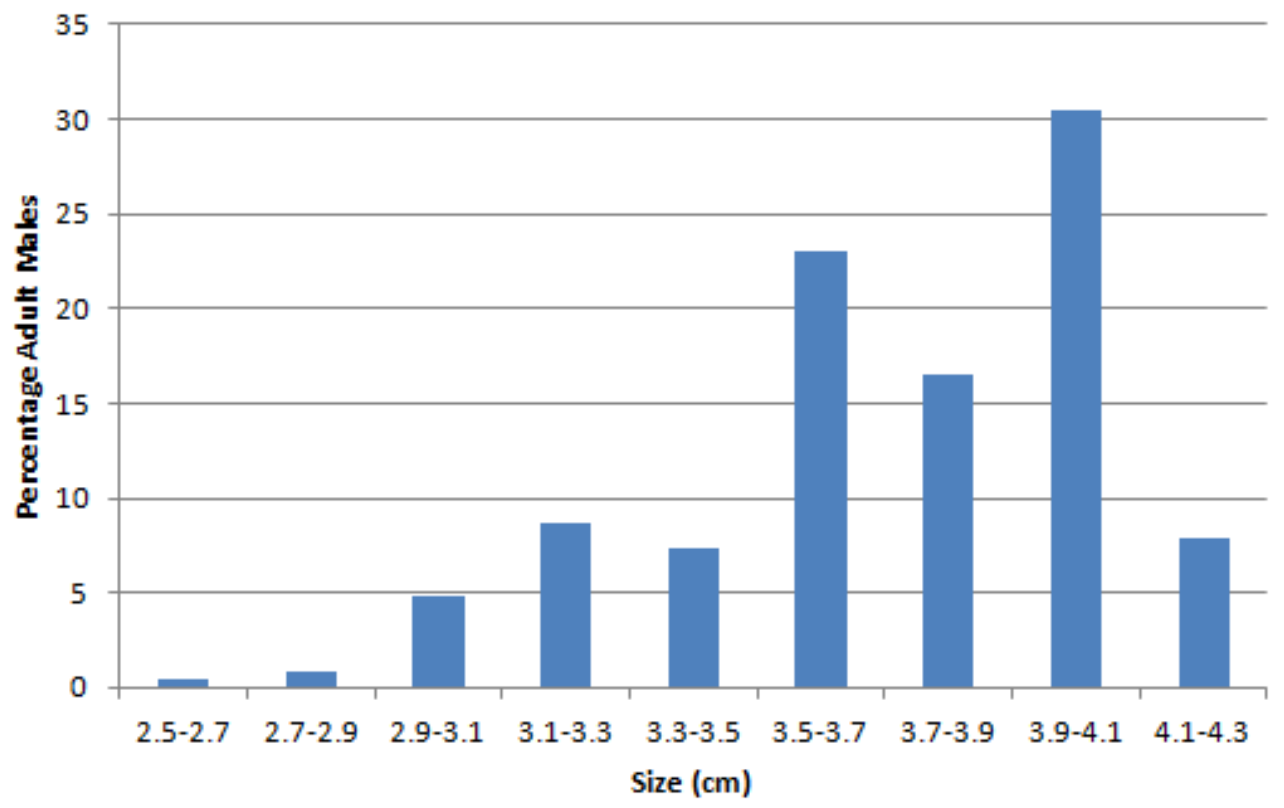

Fig. 7. Size classes of adult male crabs at Eagle Island

Figs. 10 and 11 show the size classes of adult female crabs at Rumuolumeni and Eagle Island respectively. Seven size classes were observed at Rumuolumeni (Fig. 10), having a minimum percentage occurrence in class of 4.4 to $4.6 \mathrm{~cm}$, high percentage occurrence in class sizes $3.2-3.4 \mathrm{~cm}(21 \%) ; 3.4-3.6 \mathrm{~cm}$
(19\%); 4.0-4.2 (16\%) and $3.0-3.2 \mathrm{~cm}(16 \%)$. At Eagle Island, ten classes were derived (Fig. 11). The least percentage occurrence of adult females occurred in size class $3.1-3.3 \mathrm{~cm}(1.7 \%)$ and the highest occurrence was observed in size class $3.5-3.7 \mathrm{~cm}$ (43\%). 


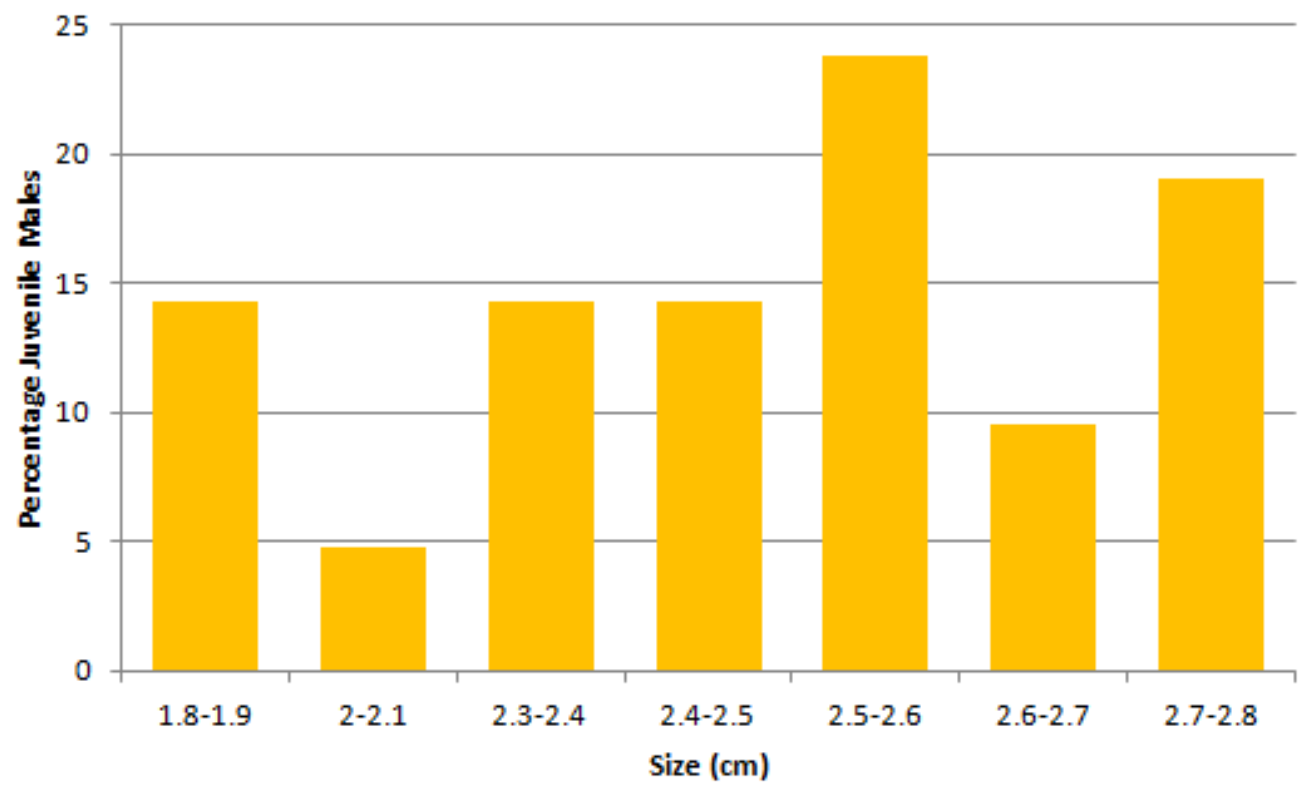

Fig. 8. Size classes of juvenile male crabs at Rumuolumeni

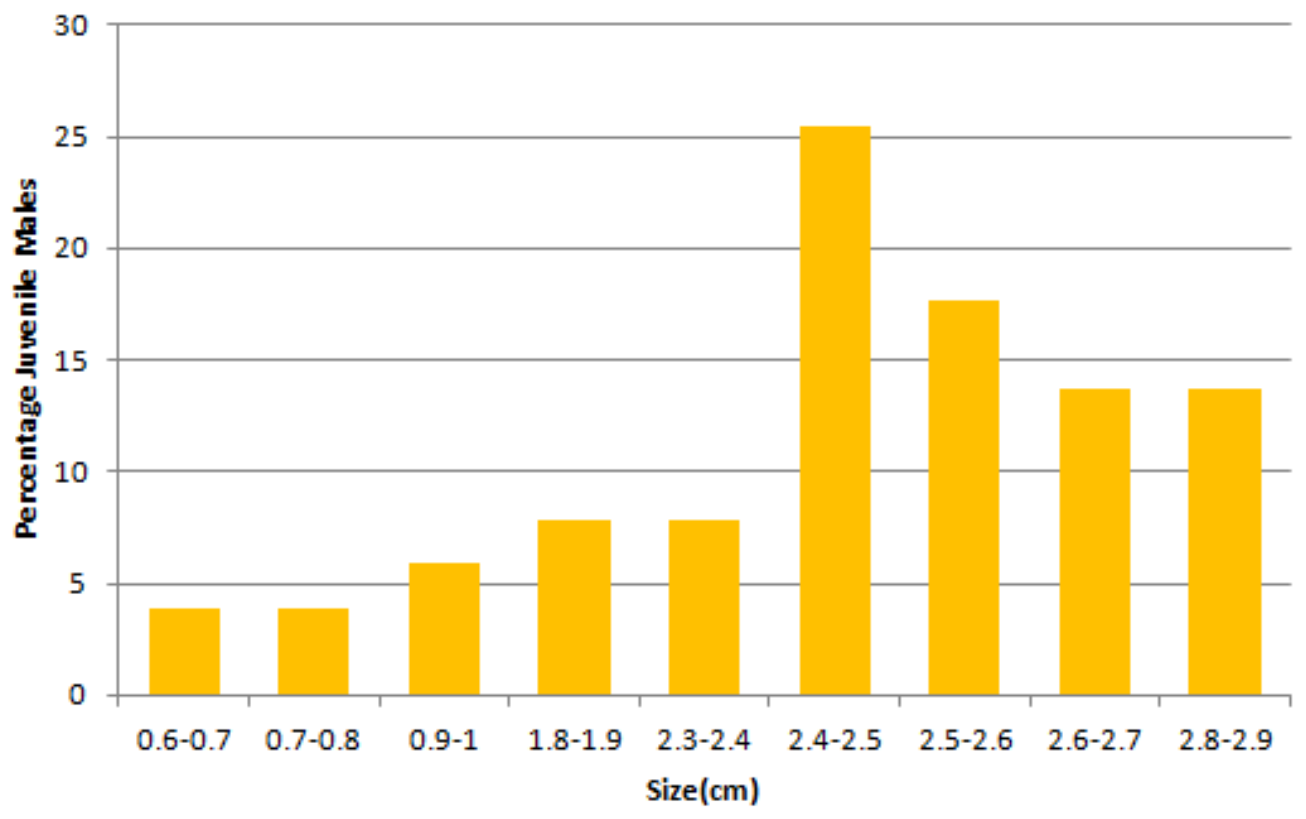

Fig. 9. Size classes of juvenile male crabs at Eagle Island

Figs. 12 and 13 show the size classes of juvenile female crabs at Rumuolumeni and Eagle Island respectively. Six size classes were derived at Rumuolumeni (Fig. 12). The least percentage occurrence of juvenile females occurred in size class $2.8-2.9 \mathrm{~cm}(5 \%)$ while the highest occurrence occurred in size class
$2.2-2.3 \mathrm{~cm}$ (45\%). At Eagle Island, (Fig. 13) five classes were derived. The least percentage occurrence of juvenile females occurred in size class $2.6-2.7 \mathrm{~cm}$ and $2.8-2.9$ $\mathrm{cm} \quad(3.9 \%)$ while the highest occurrence occurred in size class $2.4-2.5 \mathrm{~cm}$ (33.3\%). 


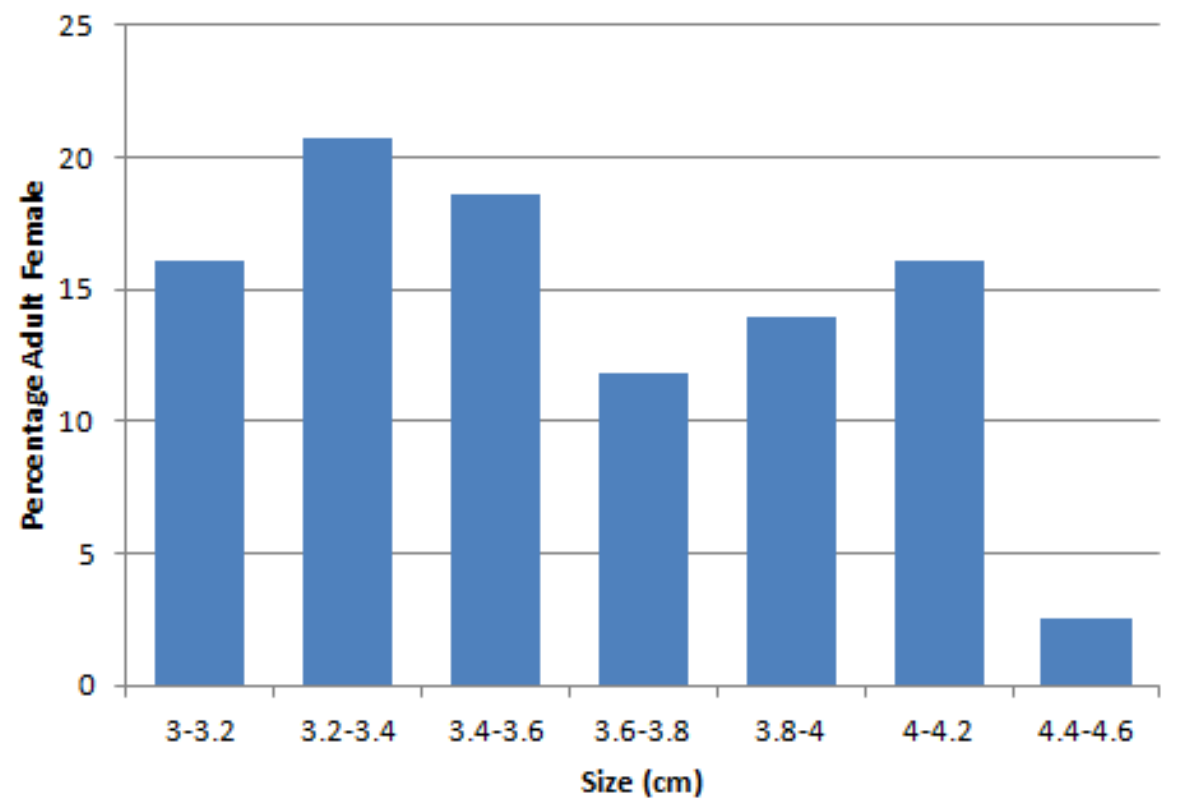

Fig. 10. Size classes of adult female crabs at Rumuolumeni

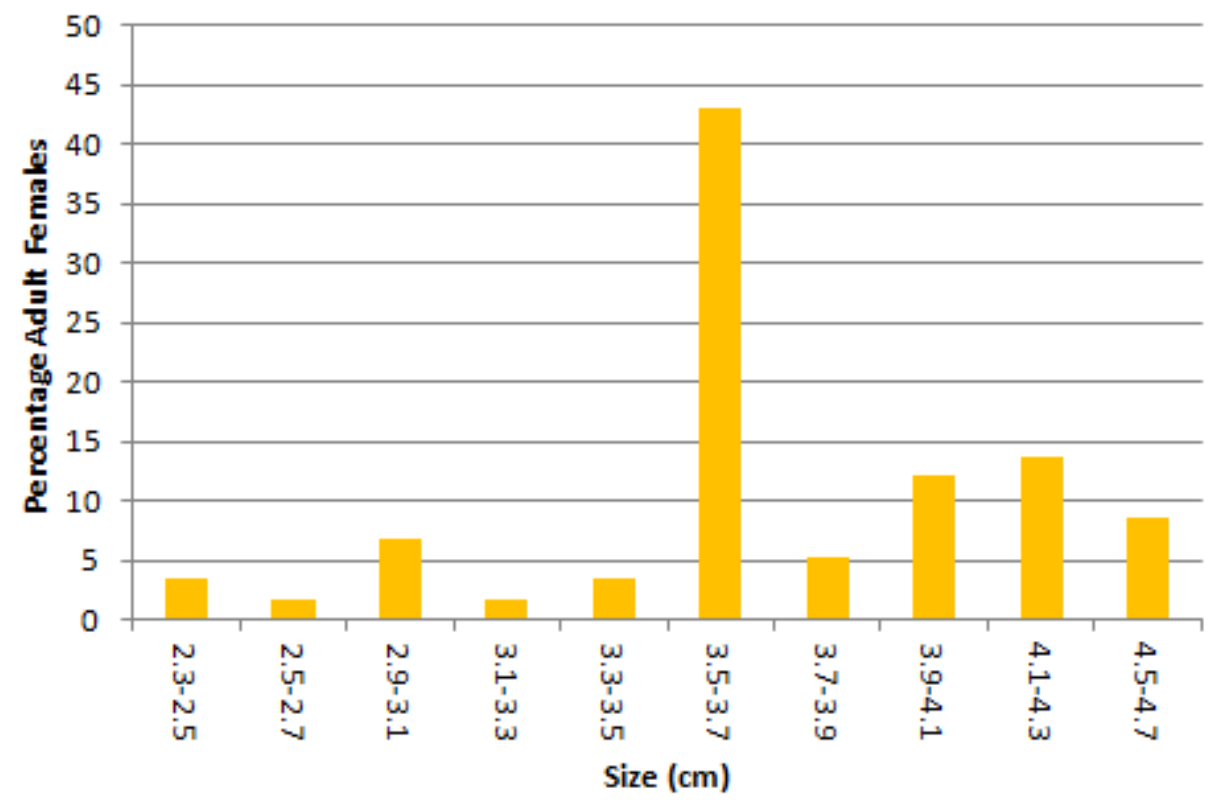

Fig. 11. Size classes of adult female crabs at Eagle Island

\section{DISCUSSION}

In this rapid assessment, the study shows contrasting sex ratio in two mangrove habitats for both adult and juvenile crabs of the Uca tangeri species. Sex ratio is important for explaining structure in animal populations. For marine and estuarine crab populations, the ratio of $1: 1$ has been shown by a few workers $[5,9,10,11,12,13]$. The highly significant $(\mathrm{X} 2$ test, $\mathrm{P}<0.05)$ contrasting adult sex ratio of $4: 1$ of male to female at Eagle Island and 1:2.6 at Rumuolumeni and or juveniles showing 2.4:1 (Eagle Island) and 1:1.8 (Rumuolumeni) support evidence of deviation in Uca spp. from the 1:1 proportion $[14,15,16,17,18,19,20,21]$. 


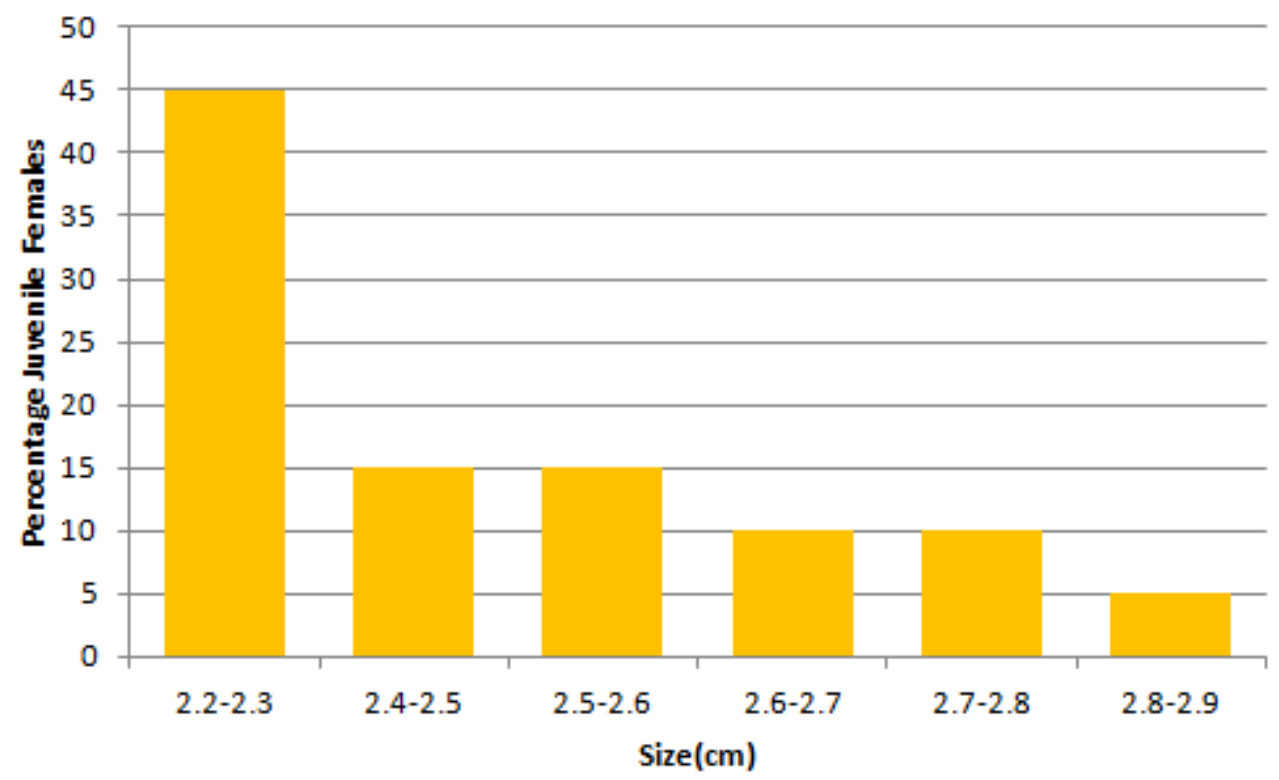

Fig. 12. Size classes of juvenile female crabs at Rumuolumeni

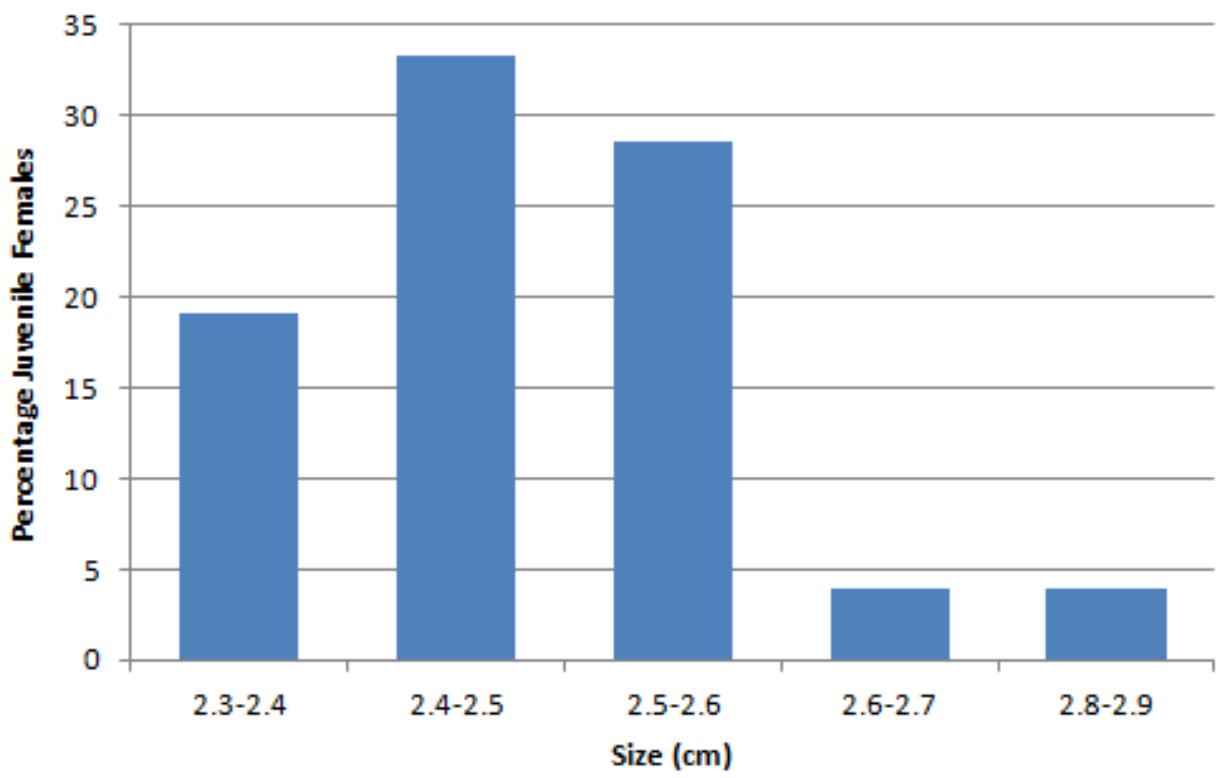

Fig. 13. Size classes of juvenile female crabs at Eagle Island

In the present study, the sex ratio deviation towards males at Eagle Island or females at Rumuolumeni is high and indicates possible effects of environmental and anthropogenic factors on continuous recruitment.

The observed results of recruitment from size classes do not support the anthropogenic factor as they were not significantly different $(P<0.05)$ in any of the categories in both habitats. Among the adults, the size classes were similar, ranging from 2.5 to 4.7. Similarly the adult females in both habitats ranged from 2.3 to 4.7. A similar range was observed in the juvenile category. In comparison also, recruitment was not influenced by the anthropogenic uses by the communities as there was no significant difference between Eagle Island and 
Rumuolumeni for food (53\% and 48\%); commerce (38\% and $63 \%)$; medicine $(49 \%$ and $51 \%)$; trap material (53\% and $47 \%)$; and cultural and religious purpose $(50 \%$ and $50 \%)$ respectively.

Thus, the evidence to understand the contrasting sex ratios in the two local mangrove habitats is more likely environmental than anthropogenic. The larval phases which are dispersed within the estuarine system predispose them to have equal access to the mangrove habitats and therefore to have equivalent sex ratios. Some studies have shown in mangrove habitats that the settling of megalopae, juveniles and adult fiddler crabs is the same in intertidal habitats in mangrove areas $[22,23]$. Recruitment and habitat selection by megalopae has also been shown to be facilitated by two factors, namely their abundance in estuarine waters from nearshore areas and their detection of physical and chemical stimuli in the presence of conspecifics $[24,25,26,27,28,29,30]$. However, in the present study, equal access by megalopae to the mangrove habitats and the presence of conspecifics do not seem to explain the contrasting sex ratios in the study. What might account for the differences in sex ratio can be explored through survival studies of megalopae from first instar to the seventh crab instar in each habitat. Current studies on megalopae resettlement cues $[31,32,33,34,35,36]$ provide guidance in this regard showing the delay or immediate settlement depending on substratum cues and water soluble pheromones. Further investigations need to explore the possible effect of potential differences in substratum cues and water soluble pheromones with respect to the dominant gender. This would provide emerging insights and a basis for conservation planning for this species in the emerging twin threats of mangrove deforestation and uncontrolled socioeconomic exploitation.

\section{CONCLUSION}

Sex ratio in two mangrove habitats within the Bonny River system has shown a deviation from the documented $1: 1$ ratio. The deviation is significant having a male dominated gender at Eagle Island site and Female dominated gender at Rumuolumeni site. An assessment of recruitment cues in relation to the dominant gender in each mangrove habitat is critical for future conservation planning and interpretation during ecological surveys.

\section{ETHICAL APPROVAL}

As per international standard or university standard written ethical approval has been collected and preserved by the author(s).

\section{COMPETING INTERESTS}

Authors have declared that no competing interests exist.

\section{REFERENCES}

1. Roddie BD, Leakey RJ, Berry AJ. Salinitytemperature tolerance and osmoregulation in Eurytemora affinis (Poppe) (Copepoda: Calanoida) in relation to its distribution in the zooplankton of the upper reaches of the Forth estuary. Journal of Experimental Marine Biology and Ecology. 1984;79(2): 191-211.

2. Lin $\mathrm{HC}, \mathrm{Su} Y \mathrm{YC}, \mathrm{Su} \mathrm{SH}$. A comparative study of osmoregulation in four fiddler crabs (Ocypodidae: Uca). Zoological Science. 2002;19(6):643-51.

3. Anderson RC. An underwater guide to Indonesia. University of Hawaii Press; 2000.

4. Genoni GP. Increased burrowing by fiddler crabs Uca rapax (Smith) (Decapoda: Ocypodidae) in response to low food supply. Journal of Experimental Marine Biology and Ecology. 1991;147(2):267-85.

5. Hartnoll RG, Broderick AC, Godley BJ, Saunders KE. Population structure of the land crab Johngarthia lagostoma on Ascension Island. Journal of Crustacean Biology. 2009;29(1):57-61.

6. Gregati RA, Negreiros-Fransozo ML. Relative growth and morphological sexual maturity of Chasmagnathus granulatus (Crustacea, Varunidae) from a mangrove area in southeastern Brazilian coast. Iheringia. Série Zoologia. 2007;97(3):26872.

7. Conti RD, Nalesso RC. Status of the population structure of the mangrove crab Ucides cordatus (Decapoda: Ocypodidae) on the Piraquê-açu River estuary, Espírito Santo, Brazil. Brazilian Journal of Oceanography. 2010;58(2):81-92.

8. Sokal RR, Rohlf FJ. Biometry WH Freeman and Company. San Francisco. $1981 ; 859$.

9. Costa TM, Negreiros-Fransozo ML. Population biology of Uca thayeri Rathbun, 
1900 (Brachyura, Ocypodidae) in a subtropical South American mangrove area: Results from transect and catch-perunit-effort techniques. Crustaceana. 2003;75(10):1201-18.

10. Koch V, Wolff M, Diele K. Comparative population dynamics of four fiddler crabs (Ocypodidae, genus Uca) from a North Brazilian mangrove ecosystem. Marine Ecology Progress Series. 2005;291:17788.

11. Bezerra LE, Matthews-Cascon HE. Population structure of the fiddler crab Uca leptodactyla Rathbun, 1898 (Brachyura: Ocypodidae) in a tropical mangrove of northeast Brazil. Thalassas. 2006;22(1): 65-74.

12. Bezerra LE, Matthews-Cascon $\mathrm{H}$. Population and reproductive biology of the fiddler crab Uca thayeri Rathbun, 1900 (Crustacea: Ocypodidae) in a tropical mangrove from Northeast Brazil. Acta Oecologica. 2007;31(3):251-8.

13. da Silva Castiglioni $\mathrm{D}$, Almeida $\mathrm{AO}$, Bezerra LE. More common than reported: Range extension, size-frequency and sexratio of Uca (Minuca) victoriana (Crustacea: Ocypodidae) in tropical mangroves, Brazil. Marine Biodiversity Records. 2010;3:8.

14. Wolf PL, Shanholtzer SF, Reimold RJ. Population estimates for Uca pugnax (Smith, 1870) on the Duplin estuary marsh, Georgia, USA (Decapoda Brachyura, Ocypodidae). Crustaceana. 1975;79-91.

15. Frith DW, Brunenmeister S. Ecological and population studies of fiddler crabs (Ocypodidae, genus Uca) on a mangrove shore at Phuket Island, western Peninsular Thailand. Crustaceana. 1980;157-84.

16. Colby DR, Fonseca MS. Population dynamics, spatial dispersion and somatic growth of the sand fiddler crab Uca pugilalor. Mar. Ecol. Prog. Ser. 1984;16: 269-279.

17. Spivak ED, Gavio MA, Navarro CE. Life history and structure of the world's southernmost Uca population: Uca uruguayensis (Crustacea, Brachyura) in Mar Chiquita Lagoon (Argentina). Bulletin of Marine Science. 1991;48(3):679-88.

18. Emmerson WD. Seasonal breeding cycles and sex ratios of eight species of crabs from Mgazana, a mangrove estuary in Transkei, southern Africa. Journal of Crustacean Biology. 1994;14(3):568-78.
19. Ali MY, Kamal D, Hossain SM, Azam MA, Sabbir W, Murshida A, Ahmed B, Azam K. Biological studies of the mud crab, Scylla serrata (Forskal) of the Sundarbans mangrove ecosystem in Khulna region of Bangladesh. Pakistan Journal of Biological Sciences. 2004;7(11):1981-7.

20. Litulo C. Population structure and reproduction of the hermit crab Dardanus deformis (Anomura: Diogenidae) in the Indian Ocean. Journal of the Marine Biological Association of the United Kingdom. 2005;85(4):883-7.

21. Litulo C. Population structure and reproduction of the hermit crab Dardanus deformis (Anomura: Diogenidae) in the Indian Ocean. Journal of the Marine Biological Association of the United Kingdom. 2005;85(4):883-7.

22. Krebs CT, Valiela I. Effect of experimentally applied chlorinated hydrocarbons on the biomass of the fiddler crab, Uca pugnax (Smith). Estuarine and Coastal Marine Science. 1978;6(4):375-86.

23. O'Connor NJ. Settlement and recruitment of the fiddler crabs Uca pugnax and $U$. pugilator in a North Carolina, USA, salt marsh. Marine Ecology-Progress Series. 1993;93:227.

24. Christy JH. Burrow structure and use in the sand fiddler crab, Uca pugilator (Bosc). Animal Behaviour. 1982;30(3):687-94.

25. Meredith WH. The dynamics of zooplankton and micronekton community structure across a salt marsh-estuarine waters interface of lower Delaware Bay. Ph.D. Dissertation, Univ. Delaware, Newark, Delaware. 1982;381.

26. Epifanio CE, Dittel Al, Park S, Schwalm S, Fouts A. Early life history of Hemigrapsus sanguineus, a non-indigenous crab in the Middle Atlantic Bight (USA). Marine Ecology Progress Series. 1998;170:231-8.

27. Jensen GC. Gregarious settlement by megalopae of the porcelain crabs Petrolisthes cinctipes (Randall) and P. eriomerus Stimpson. Journal of Experimental Marine Biology and Ecology. 1989;131(3):223-31.

28. Little KT, Epifanio CE. Mechanism for the re-invasion of an estuary by two species of brachyuran megalopae. Marine ecology progress series. Oldendorf. 1991;68(3): 235-42.

29. Christy JH. Rapid development of megalopae of the fiddler crab Uca pugilator reared over sediment: Implications for 
models of larval recruitment. Marine Ecology Progress Series; 1989.

30. O'Connor NJ. Flexibility in timing of the metamorphic molt by fiddler crab megalopae Uca pugilator. Marine ecology progress series. Oldendorf. 1991;68(3): 243-7.

31. Rodriguez RA, Epifanio CE. Multiple cues for induction of metamorphosis in larvae of the common mud crab Panopeus herbstii. Marine Ecology Progress Series. 2000;195:221-9.

32. Andrews WR, Targett NM, Epifanio CE. Isolation and characterization of the metamorphic inducer of the common mud crab, Panopeus herbstii. Journal of Experimental Marine Biology and Ecology. $2001 ; 261(1): 121-34$.

33. Anger $\mathrm{K}$, Torres $\mathrm{G}$, Giménez $\mathrm{L}$. Metamorphosis of a sesarmid river crab, Armases roberti: Stimulation by adult odours versus inhibition by salinity stress. Marine and Freshwater Behaviour and Physiology. 2006;39(4):269-78.

34. Diele K, Simith DJ. Effects of substrata and conspecific odour on the metamorphosis of mangrove crab megalopae, Ucides cordatus (Ocypodidae). Journal of Experimental Marine Biology and Ecology. 2007;348(1-2):174-82.

35. Simith DJ, Diele K. Metamorphosis of mangrove crab megalopae, Ucides cordatus (Ocypodidae): Effects of interspecific versus intraspecific settlement cues. Journal of Experimental Marine Biology and Ecology. 2008;362(2):101-7.

36. Krimsky LS, Epifanio CE. Multiple cues from multiple habitats: Effect on metamorphosis of the Florida stone crab, Menippe mercenaria. Journal of Experimental Marine Biology and Ecology. 2008;358(2):178-84.

(C) 2019 Torle et al.; This is an Open Access article distributed under the terms of the Creative Commons Attribution License (http://creativecommons.org/licenses/by/4.0), which permits unrestricted use, distribution, and reproduction in any medium, provided the original work is properly cited.

Peer-review history:

The peer review history for this paper can be accessed here: http://www.sdiarticle3.com/review-history/47957 